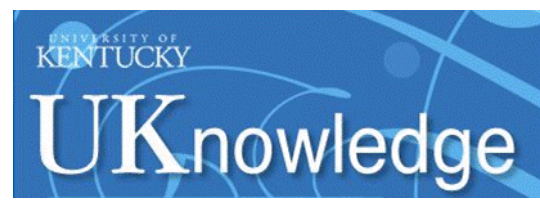

University of Kentucky

UKnowledge

\title{
Carbon Isotope Discrimination, Selection Response, and Forage Production of Tall Fescue in Contrasting Environments
}

R. C. Johnson

U.S. Department of Agriculture

Andrew A. Hopkins

Samuel Roberts Noble Foundation

M. A. Evans

Washington State University

Follow this and additional works at: https://uknowledge.uky.edu/igc

Part of the Plant Sciences Commons, and the Soil Science Commons

This document is available at https://uknowledge.uky.edu/igc/21/12-1/22

The XXI International Grassland Congress / VIII International Rangeland Congress took place in Hohhot, China from June 29 through July 5, 2008.

Proceedings edited by Organizing Committee of 2008 IGC/IRC Conference

Published by Guangdong People's Publishing House

This Event is brought to you for free and open access by the Plant and Soil Sciences at UKnowledge. It has been accepted for inclusion in International Grassland Congress Proceedings by an authorized administrator of UKnowledge. For more information, please contact UKnowledge@lsv.uky.edu. 


\title{
Carbon isotope discrimination, selection response, and forage production of tall Fescue in contrasting environments
}

\author{
R.C.Johnson ${ }^{1}, A$ A. Hopkins ${ }^{2}, M . A$. Evans $^{3}$ \\ ${ }^{1}$ USDA-ARS, Box 646402, Washington State University, Pullman WA 99164,USA,E-mail:rcjohnson@wsu.edu, \\ ${ }^{2}$ Samuel Roberts Noble Foundation, A rdmore OK, USA , ${ }^{3}$ Department of Statistics, Washington State University, Pullman \\ WA $99164, U S A$
}

Key words : Festuca arundinacea ,water use efficiency ,forage production ,drought

Introduction Carbon isotope discrimination $(\Delta)$ usually correlates with the dry matter to transpiration ratio (transpiration efficiency, TE) in C3 species, with low $\Delta$ corresponding high TE. But its heritability and relationship to forage production is less clear. In a four year study of tall fescue (Festuca arundinacea Schreb.) at Pullman, WA (relatively cool with low humidity) and Ardmore, OK (relatively hot with high humidity) we determined 1) if $\Delta$ differences in divergently selected populations made on single plants were maintained in solid seeded plots, and 2) how $\Delta$ in selected populations and a set of four cultivars was related to forage production.

Materials and methods At Pullman W A (46.72446 N and $117.13554 \mathrm{~W})$ and Ardmore OK (34.19250 N and 97.08556 W) plots $4.6 \times 1.5 \mathrm{~m}$ were established. The seeding rate was $28.7 \mathrm{~kg}$ seed $\mathrm{ha}^{-1}$ at both locations. Seven tall fescue entries were randomized in complete blocks with three replications at both locations and plots were maintained under dry-land conditions according to locally recommended fertility rates and procedures. Prior to each harvest, samples of upper, fully emerged leaves were collected from 10-12 plants per plot, dried at $70^{\circ} \mathrm{C}$ to constant weight, and carbon isotope discrimination was determined at the Augustana College (Sioux Falls, SD , USA) stable isotope laboratory. At Ardmore, plots were harvested in Jan . 2003. May 2003 , Jan . 2004 , July 2004 , Dec . 2004 , and June 2005 . At Pullman , harvests were in Sept . 2002 , and July 2003 , 2004 , and 2005 . For each date, forage from each plot was cut about $7.5 \mathrm{~cm}$ above ground level, removed, dried, and forage production calculated on a dry weight basis .

Table 1 Forage production and carbon isotope discrimination for seven entries of tall fescue averaged over four harvest dates from 2002 to 2005 at A rdmore $O K$ and Pullman. WA

\begin{tabular}{|c|c|c|c|c|c|}
\hline \multicolumn{3}{|c|}{ Ardmore } & \multicolumn{3}{|c|}{ Pullman } \\
\hline Entry ${ }^{\dagger}$ & Dry wt. & $\Delta$ & Entry & Dry wt & $\Delta$ \\
\hline & $\mathrm{Kg} \mathrm{ha}{ }^{-1}$ & $\% 0$ & & $\mathrm{Kg} \mathrm{ha}^{-1}$ & $\% 0$ \\
\hline JesupE + & $2397 \mathrm{a}^{\dagger}$ & $20.25 \mathrm{c}$ & K31 low & $6937 a$ & $18 \mathrm{A7d}$ \\
\hline K31 base & 2088ab & $20.41 b c$ & Alta & $6931 \mathrm{a}$ & $19.03 \mathrm{~b}$ \\
\hline K31 low & 2084ab & 19 99d & JesupE + & $6885 \mathrm{a}$ & $19.08 b$ \\
\hline K31 C & $2066 b$ & $20.51 \mathrm{~b}$ & Fawn & $6583 \mathrm{ab}$ & $19.46 a$ \\
\hline Alta & $1940 \mathrm{bc}$ & $20.52 \mathrm{~b}$ & K31 base & 6535ab & $18.82 c$ \\
\hline Fawn & 1916 bc & $20.58 \mathrm{ab}$ & K31 C & $6438 a b$ & $19.20 \mathrm{~b}$ \\
\hline K31 high & $1697 \mathrm{c}$ & $20.75 a$ & K31 high & $6329 \mathrm{~b}$ & $19.43 a$ \\
\hline
\end{tabular}

$\dagger$ Within a site, means follow ed by different letters are different at the $\mathrm{P}<0.05$ level .

$\ddagger \mathrm{K} 31$ refers to the cv. Kentucky 31 ; low and high refer to selections for high and low $\Delta$, respectively ; base to the initial selection population; K31 C refers to a commercial source of Kentucky 31 ; and E+ to highly endophyte infected germplasm .

Results Differences in $\Delta$ for low and high $\Delta$ populations selected on spaced plants (Johnson and Li Yangyang, 1999) were maintained in solid seeded plots at both Pullman and Ardmore (Table 1). At Pullman, the low $\Delta$ selection (high TE) had higher production than the high $\Delta$ selection (low TE) with the base population intermediate. Partial correlations with all entries between $\Delta$ and forage production, controlling for harvest date effects, were not significant. How ever, partial correlation between $\Delta$ and forage production on the selected and base populations $\mathrm{w}$ as significant $\left(\mathrm{r}=-0.59^{*}, \mathrm{n}=12\right)$ at $\mathrm{Pullman}$, although not at Ardmore.

Conclusions The data show selection for low $\Delta$ (high transpiration efficiency) is possible and may improve forage production in some environments, but not consistently. Therefore, selection for $\Delta$ should not be the main focus of a breeding prog ram despite its heritable nature For breeding tall fescue, one cycle of phenotypic selection for low $\Delta$ in advanced material is recommended

\section{Reference}

Johnson, R .C and Li Yangyang . 1999. Water relations, forage production, and photosynthesis in tall fescue divergently selected for carbon isotope discrimination . Crop Sci . 39 :1663-1670. 